\title{
高温塩酸水溶液に対するチタンの耐食性*
}

伊 藤 順一** 北 村 義 治**

\section{Corrosion Resistance of Titanium in Hydrochloric Acid Solution at Elevated Temperature}

Jun-ichi Itô and Yoshiharu Kitamura

The corrosion resistance of titanium was investigated in aqueous solutions of $0.10 \sim 1.00 \% \mathrm{HCl}$ at elevated temperatures of $100 \sim 180^{\circ} \mathrm{C}$. The total immersion corrosion test and the cell voltagecurrent curve method were used to evaluate the corrosion rate.

\section{1. 緒訔}

チタンの耐食性について, 沸点以下の温度の各種腐食 環境に対する研究は多く発表されているが，さらに高温 における研究法今日までほとえど行なわれていない。本 報は，沸点 $180^{\circ} \mathrm{C}$ の塩酸水溶液に対するチタンの耐食 性について, 重量変化および発生電流特性 ${ }^{1,2)}$ の測定に より検討したものである。

\section{$2 \cdot 1$ 試 験 片}

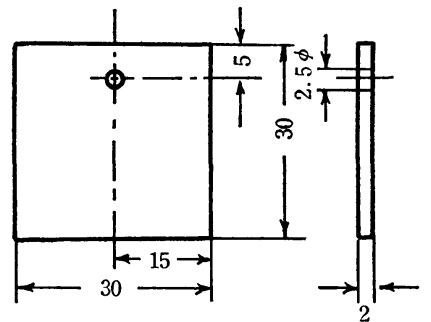

図 1 重量变化測定試験片
試験片の化学組成 它表 1 に, 形状, 寸 法を図 1, 2 に示し た。試験片の表面 は, JIS R-6251 研 摩布の 400 番まで仕 上研摩後, 脱脂, 洗 浄した後ただちに 試験溶液に浸漬してそれぞれの試験を行なった。

表 1 試験片の化学組成

\begin{tabular}{c|c|c|c|c|c|c|c}
\hline \hline 成分 & $\mathrm{H}_{2}$ & $\mathrm{O}_{2}$ & $\mathrm{~N}_{2}$ & $\mathrm{Si}$ & $\mathrm{Fe}$ & $\mathrm{C}$ & $\mathrm{Ti}$ \\
\hline$\%$ & 0.0010 & 0.072 & 0.0047 & 0.008 & 0.046 & 0.004 & $\mathrm{Bal}$ \\
\hline
\end{tabular}

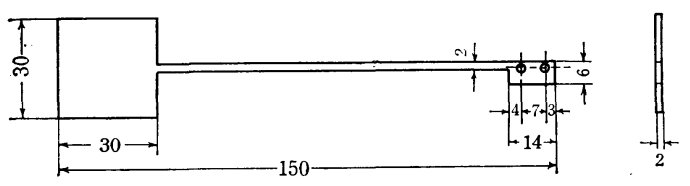

図 2 発生電流测定試験片

\section{2 試験溶液および試験環境}

塩酸濃度は, 高温環境におけるチタンの耐食限界から 想定して $0.1 \%$ 1\% とし，塩酸は試薬特級品を用い，

* 昭和 39 年 4 月 1 日 化学工学協会第 29 年会 (東京) 飞未小て発表

** 味の素株式会社中央研究所（川崎市鈴木町 2964）
The results obtained showed an abrupt increase in the corrosion rate at the $\mathrm{HCl}$ concentration of $0.8 \%$ and above. It was suggested that the corrosion behavior of titanium changes markedly at a $\mathrm{HCl}$ concentration between 0.6 and $0.8 \%$.

比抵抗 $5 \times 10^{6} \Omega-\mathrm{cm}$ のイオン交換樹脂純水により調整 した。また，試験温度は各塩酸濃度についてそれぞれ沸 点 $180^{\circ} \mathrm{C}$ とした。試験時間は，重量変化測定試験の場 合 20 時間，発生電流測定試験の場合はとれぞれの試験 環境に 10 時間浸漬保持の後，測定を行なった。

\section{3. 試 験 装 置}

重量変化測定試験は，沸点においては逆流コンデンサ 一付 $1 l$ ガラスフラスコを用い，沸点をこえる温度にお いては，チタンライニング製オートクレーブ中に熱媒体 を介して硬質ガラス製ビーカーを入れて行なった。

発生電流測定試験に用いた回路のブロック線図を図 3 に，測定用オートクレーブの断面図を図 4 に，また，そ の外観写真を図 5，6 に示した。このような装置を用い ると，高温，高圧のもとで発生電流を測定するのに有効 である。

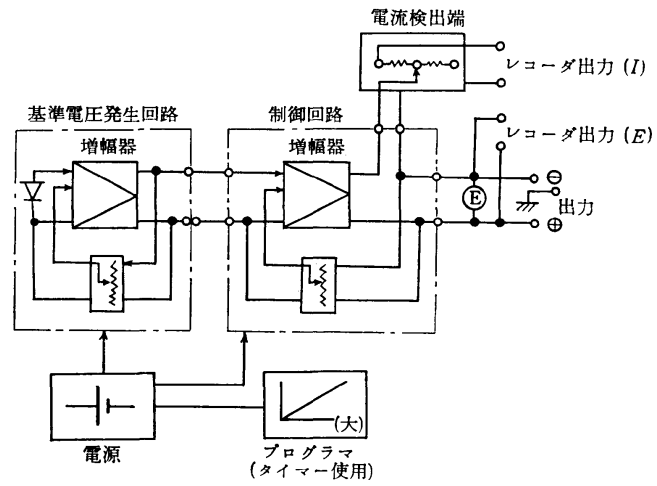

図 3 発生電流測定回路ブロック線図

\section{4. 試 験 結 果}

塩酸濃度が $0.10,0.30,0.40,0.60,0.80$ および $1.00 \%$ ，温度が沸点， $120 ， 155$ および $180^{\circ} \mathrm{C}$ における 重量变化測定試験の結果から算定された腐食速度の值を 


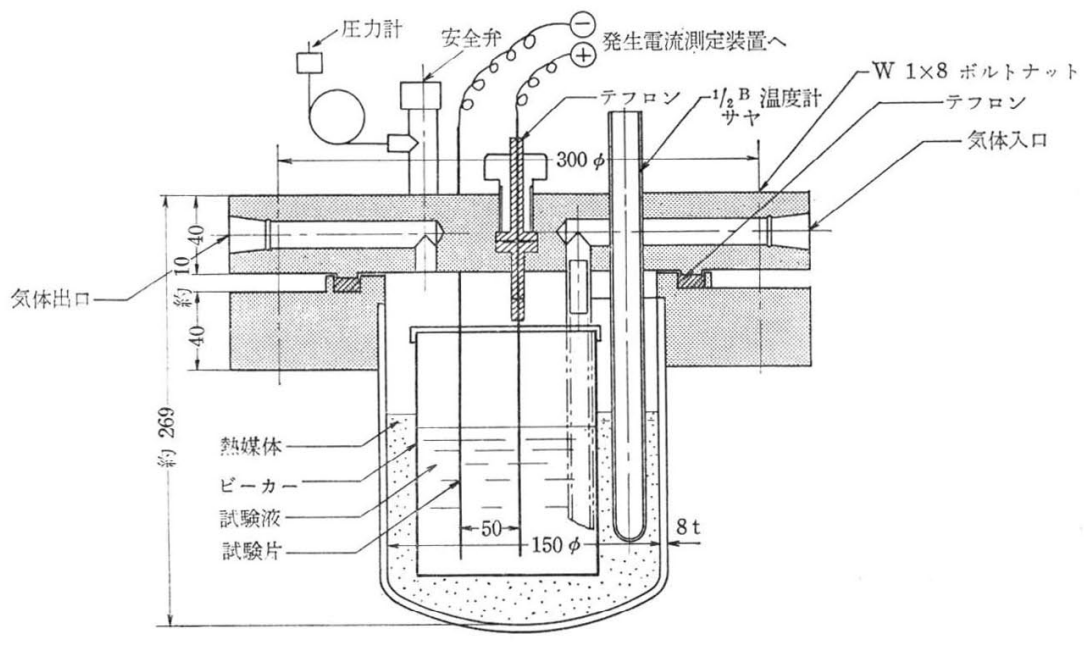

図 4 発生電流測定オートクレーブ断面図

1. 材留：接液部 SUS 32 その他 SS 41 2. 設計圧力: $30 \mathrm{~kg} / \mathrm{cm}^{2} \mathrm{G} 220^{\circ} \mathrm{C}$
表 2 に，また塩酸濃度が $0.30,0.60,0.80$ および $1.00 \%$ の沸点 $(100 \sim 101$ $\left.{ }^{\circ} \mathrm{C}\right)$ における発生電流測定 試験の結果を図7に示し た。

表 2 の重量変化測定試験 結果から，0.4\% 以下の濃 度の塩酸水溶液で温度が $180^{\circ} \mathrm{C}$ 以下の場合, チタン は受動態被膜を維持して完 全な耐食性を示し，濃度， 温度間に有意差はみられな い。しかるに，濃度 $0.8 \%$ 以上になると侵食度は急激 に增大し，濃度間に高度の

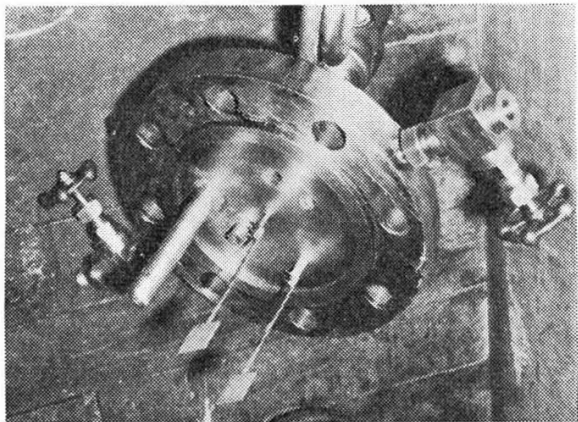

図 5 発生電流測定オートクレーブ蓋部

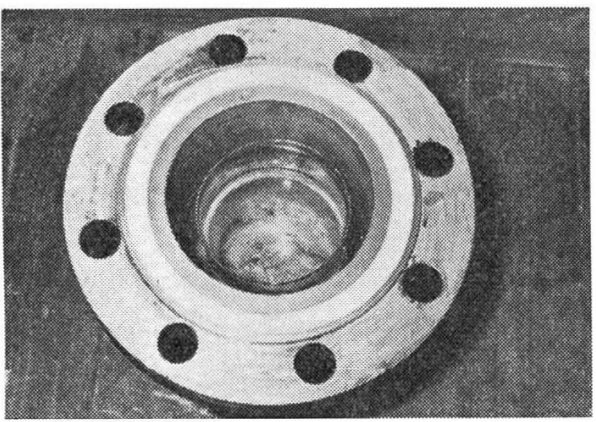

図 6 発生電流測定オートクレーブ本体

表 2 チタンの塩酸中における腐食速度 $(\mathrm{mm} / \mathrm{yr})$

\begin{tabular}{c|c|c|c|c}
\hline \hline 温度 $\left(^{\circ} \mathrm{C}\right)$ & 沸 点 & 120 & 155 & 180 \\
\hline 0.10 & 0.00 & 0.00 & 0.00 & 0.00 \\
\hline 0.30 & 0.00 & 0.00 & 0.00 & 0.00 \\
\hline 0.40 & 0.00 & 0.00 & 0.00 & 0.00 \\
\hline 0.60 & 0.04 & 0.00 & 0.00 & 0.04 \\
\hline 0.80 & 1.81 & 2.33 & 26.36 & 28.23 \\
\hline 1.00 & 2.38 & - & - & - \\
\hline
\end{tabular}

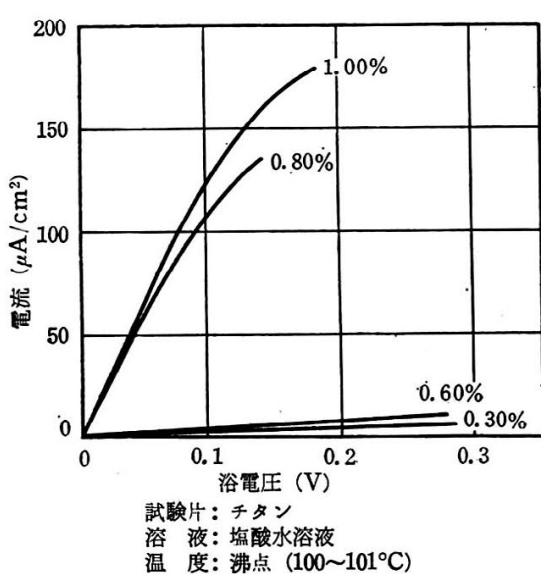

図 7 発生電流測定試験結果

有意差が認 められる。 また, 図 7 の発生電流 測定試験結 果からも， 沸点におい て同一の傾 向が認めら れる。

5. 結 言 高温塩酸 水溶液に対 するチタン の耐食性を確かめるため, 重量变化および発生電流特性 を測定し，解析した結果，チタンは，沸点〜 $180^{\circ} \mathrm{C}$ の範 囲の試験において，塩酸濃度 $0.6 \%$ から $0.8 \%$ の間に受 動態一活性態の遷移点があるものと考えられる。また， 本試験の腐食環境において, 重量変化測定法と発生電流 測定法による試験結果には相関性を認めることができ る。

本報は，塩酸水溶液を対象としたが，引き続き他の無 機酸，有機酸類に対する高温の耐食性についても試験を 行なう予定である。終りに本研究を行なうにあたり，ご 指導を賜わった日本大学山本洋一教授, 大阪大学多賀谷 正義名誉教授に感謝の意を表する。

（昭和 39 年 9 月 3 日受理）

文 献

1）山本：化学機橶協会年報，3 (1939)

2) 北村，鈴木，岡野：防触技術，12，No. 6, 6 (1963) 